\title{
ELECTORAL INSTITUTIONS AND LEGISLATIVE BEHAVIOR Explaining Voting Defection in the European Parliament
}

\author{
By SIMON HIX*
}

\section{INTRODUCTION: ELECTORAL INSTITUTIONS AND LEGISLATIVE BEHAVIOR}

\begin{abstract}
A core assumption in contemporary political science is that "electoral institutions matter." Scholars have thoroughly theorized and investigated the effects of electoral rules on macrolevel political phenomena such as the proportionality of parliamentary representation, the number of parties in a multiparty system, the stability of cabinets, and the types of policy outcomes produced. ${ }^{1}$ They have, however, conducted less theoretical and empirical research on the effects of electoral institutions on the microlevel legislative behavior of individual parliamentarians. By understanding the microlevel impact of these institutions, we can develop new explanations of other macrolevel phenomena such as legislative party cohesion.

The European Parliament, given the variety of electoral and candidateselection rules used to elect its members (MEPs), is an ideal laboratory for investigating the impact of electoral rules on legislative behavior. ${ }^{2}$
\end{abstract}

\footnotetext{
*I would like to thank Giancomo Benedetto, Clifford Carrubba, Christophe Crombez. David Epstein, David Farrell, Fabio Franchino, Matthew Gabel, Simon Hug, George Jones, Ken Kollman, Vanentino Larcinese, Paul Mitchell, Abdul Noury, Sharyn O'Halloran, Gerald Schneider, Roger Scully, and the three anonymous referees for their helpful comments on earlier versions of this article. The research for this article was funded by the Economic and Social Research Council of the United Kingdom (grant No. L213 25 2019).

${ }^{1}$ See, for example, Douglas Rac, The Political Consequences of Electoral Laws, rev. ed. (New Haven: Yale University Press, 1971); Arend Lijphart, Electoral Systems and Party Systems (Oxford: Oxford University Press, 1994); Gary Cox, Making Votes Count: Strategic Coordination in the World's Electoral Systems (Cambridge: Cambridge University Press, 1997); and Carles Boix, "Setting the Rules of the Game: The Choice of Electoral Systems in Advanced Democracies," American Political Science Review 93 (September 1999).

${ }^{2}$ Cf. Shaun Bowler and David Farrell, "Legislator Shirking and Voter Monitoring: Impacts of European Parliament Electoral Systems upon Legislator-Voter Relationships," Journal of Common Market Studies 31 (March 1993).
} 
In December 1974, when the European heads of government decided to hold continentwide "direct" elections for seats in the European Parliament, they envisaged a single electoral system in all European Union member states. Yet, almost thirty years later, after five sets of elections, these member states have failed to agree on a uniform election system and, accordingly, each member state remains free to set its own MEP election rules.

With the democratic accountability of the EU now a key item on the reform agenda, interest in creating a "single electoral system" for the European Parliament has resurfaced. Optimistic mid-1970s expectations have gone unmet; direct elections have not facilitated the development of a new European democratic identity, continentwide political parties, and a stronger connection between voters' electoral choices and EU policy outcomes. ${ }^{3}$ Instead, there has been a steady decline in voter turnout - from 63 percent in the first elections (in 1979) to 49 percent in the most recent elections (in 1999) - and throughout the EU, European elections are fought by national parties on the basis of the performance of national governments. ${ }^{4}$

Many scholars believe that adopting a single electoral system for selecting MEPs would help to reverse these trends. ${ }^{5}$ For example, Lodge and Hermann argue that the existence of different electoral systems for European and national elections would make voters more aware of the distinct purpose of European elections. ${ }^{6}$ Others claim that a single electoral system would facilitate the development of genuine transnational parties. ${ }^{7}$ However, these arguments have remained at a normative level and have not been developed theoretically or tested empirically.

This article proceeds as follows. Section II reviews the existing literature on how electoral institutions shape the relationship between politicians and parties and discusses how the effects of these institu-

\footnotetext{
${ }^{3}$ See, for example, David Marquand, Parliament for Europe (London: Cape, 1979).

${ }^{4}$ Karlheinz Reif and Hermann Schmitt, "Nine Second-Order National Elections: A Conceptual Framework for the Analysis of European Election Results," European Journal of Political Research 8:1 (1980); Cees van der Eijk and Mark Franklin, eds., Choosing Europe? The European Electorate and National Politics in the Face of Union (Ann Arbor: University of Michigan, 1996); and Michael Marsh, "Testing the Second-Order Model after Four European Elections," British Journal of Political Science 28 (October 1998).

`See, for example, Richard Corbett, Michael Shackleton, and Francis Jacobs, The European Parliament, 4th ed. (London: Catermill, 2000), 10-25.

${ }^{6}$ Juliet Lodge and Valentine Hermann, Direct Elections to the European Parliament: A Community Perspective (London: Macmillan, 1982).

${ }^{7}$ See, for example, Geoffrey Pridham and Pippa Pridham, Transnational Party Co-operation and European Integration (London: Allen and Unwin, 1981); and Rudy Andeweg, "The Reshaping of National Party Systems," in Jack Hayward, ed., The Crisis of Political Representation in Europe (London: Frank Cass, 1995).
} 
tions can be isolated in research on the European Parliament. Section III proposes a theory of legislative voting in the European Parliament that predicts the circumstances under which an MEP will defect from her parliamentary party or her national party. Section IV describes an empirical strategy for operationalizing this model in the case of the $\mathrm{Eu}$ ropean Parliament, looking at four hundred thousand individual vote decisions made in 1999 and 2000. The statistical results are presented in Section V, and Section VI contains the conclusions.

\section{Institutions and Politician-Party Relations}

\section{ELECTORAL INSTITUTIONS}

Three main electoral institutions shape the relationship between politicians and parties: the electoral system; district magnitude; and candidateselection rules. ${ }^{8}$

\section{THE ELECTORAL SYSTEM}

Different electoral systems provide different incentives for candidates. In systems in which votes cast for individual candidates-as opposed to votes cast for a party list - significantly influence each candidate's electoral fortunes, legislators seeking reelection have strategic incentives to cultivate personal support among the electorate. By contrast, in systems in which voters cannot exercise preferences for individual candidates, legislators' reelection prospects depend on the general level of support for the policies and personalities of their party leadership.

At one end of the spectrum, closed-list proportional representation (PR) systems represent the most party-centered settings. In these systems, parties present lists of candidates, and voters cannot influence the order of the candidates on them. Closed-list systems consequently allow party leaders to exert a high degree of control over their legislators. Without the strategic need to appeal directly to the electorate, candidates have no incentives to break ranks with the party line. In fact, an individual candidate has a positive incentive to go along with the party line- to improve her position on the party list.

\footnotetext{
${ }^{8}$ See, for example, Richard S. Katz, A Theory of Parties and Electoral Systems (Baltimore: Johns Hopkins University Press, 1980); Farrell, Comparing Electoral Systems (New York: Prentice Hall, 1997); David J. Samuels, "Incentives to Cultivate a Party Vote in Candidate-Centric Electoral Systems: Evidence from Brazil," Comparative Political Studies 32 (April 1999); Paul Mitchell, "Voters and Their Representatives: Electoral Institutions and Delegation in Parliamentary Democracies," European Journal of Political Research 37 (2000); and Paul Pennings and Reuven Y. Hazan, eds., "Special Issue: Democratizing Candidate Selection: Causes and Consequences," Party Politics 7 (May 2001).
} 
Some countries use semiopen- or ordered-list PR systems, in which parties propose preordered lists and voters can either vote for the party list as a whole or for an individual politician. In most countries employing these systems, however, the overwhelming majority of voters choose to vote for the preordered list rather than for individual politicians. Accordingly, votes for individual candidates rarely determine which candidates are elected. Therefore, because parties control who gets elected, most semiopen-list PR systems are, in practice, very similar to closed-list PR systems.

In the middle of the spectrum, single-member-simple-plurality (SMSP) (that is, first-past-the-post), and single-member-alternativevote or double-ballot systems promote a mixture of partisan and candidate appeals. In these systems voters choose individual candidates rather than lists of candidates from each party, an approach that encourages candidates to develop personal recognition and support in their district. These intermediate systems also allow voters to punish legislators by voting them out of office if they fail to represent their district's interests effectively. However, these systems do not allow candidates to make direct appeals against rival candidates from their own party. Therefore, few voters are aware of the specific policy differences between the candidates in their constituency and their respective party leaderships, and consequently, the general level of support for the policies and personalities of the party leaderships has a significant impact on the electoral fortunes of the candidates in each constituency-even on those of incumbent legislators. So, even in these systems, candidates have incentives to support their parties' positions, so as to increase the overall electoral competitiveness of their party. In a sense, these systems are closed, party-list systems with district magnitudes of one.

At the other end of the spectrum, fully open-list PR systems and single-transferable-vote (STV) systems represent the most candidatecentered settings. In fully open-list PR systems, candidates on each party's list are presented in no strategic order - for example, the candidates can be listed alphabetically - and voters must pick an individual candidate. The number of personal votes each candidate receives then determines the final order on the list for the allocation of seats. Similarly, in STV systems, voters exercise ordinal preferences for the candidates in multimember constituencies. To be elected, candidates are required to secure a quota of votes, and if not enough candidates meet this threshold, "second preferences" are then taken into account and so on. In both systems, there are significant incentives for candidates to cultivate personal identification and support among the electorate and 
to compete with candidates from their own party in addition to candidates from other parties. The general level of support for the policies and personalities of a party's leadership will have an impact on the number of votes cast for all the candidates from that particular party. And incumbent legislators may have a higher level of recognition than their rivals among the voters. In contrast to party-centered and intermediate systems, however, these systems provide candidates from the same party with positive incentives to differentiate themselves from other candidates in their party and, if their constituents desire it, to demonstrate their independence from their party leadership.

\section{DISTRICT MAGNITUDE}

The size of the electoral district also affects incentives for individual candidates to seek personal votes against their party leaderships. As the size of a district increases, the threat of a party leadership moving a candidate down the list decreases, because there is a greater chance in larger districts than in small districts that popular incumbents who fall out with their party leaders will stand as independent candidates and win reelection. Hence, candidates in small districts are more vulnerable to pressure from their party leaders than are candidates in large, multimember districts. ${ }^{9}$

There is no clear interaction between candidate-selection rules and district magnitude. The degree of centralization of candidate selection often depends on the number of electoral districts in a given system, as candidate selection tends to occur at the electoral district level. For example, in settings in which there is only one electoral district for the whole system, candidate selection is usually centralized. By contrast, in settings in which there are multiple electoral districts - for example, in an SMSP, STV, or a multiple-district, list PR system-candidate selection is usually decentralized. Nevertheless, even where there are several local districts and candidates are chosen by local parties, the central party leadership may still be able to exert a high level of control over local party decisions by threatening to sanction the local party if it fails to respect the wishes of the party leadership. Hence, even in multiple district systems, some parties' candidate-selection processes may be highly centralized.

\section{CANDIDATE-SELECTION RULES}

The decision as to whether a candidate will stand under a particular party label can be made centrally (by the national party executive or a

\footnotetext{
${ }^{9}$ John Carcy and Matthew S. Shugart, "Incentives to Cultivate a Personal Vote: A Rank Ordering of Electoral Formulas," Electoral Studies 14 (December 1995).
} 
national party congress) or at a lower level (by a regional or local party caucus). ${ }^{10}$ As Shattschneider famously pointed out: "He who controls the nomination owns the party." 11 The more centralized the candidateselection process is, the greater the ability of the party leadership to influence the behavior of its legislators will be.

There is, however, an interaction between candidate-selection rules and the type of electoral system used. The impact of candidate selection should be strongest in closed-ballot-list PR systems, in which the party decides whether a candidate is on the list and, if so, where on the list her name appears. The party can offer the "carrot" of a higher position on the list, and hence a greater chance of being elected or remaining in power. It can also wield the "stick" of placing a candidate lower down the list or removing her altogether. These institutions provide a high level of control by party principals over their legislative agents.

By contrast, in SMSP, fully open-list PR, and STV systems, if the candidate-selection system is centralized, the party leadership can threaten to remove a candidate from the ballot or prevent a candidate from standing under the party label if she does not toe the party line. However, in these more candidate-centered systems, a candidate rejected by a party can threaten to stand as an independent, a threat that is particularly potent when made by incumbents, as they tend to have higher recognition among their constituents than the party's prospective alternative candidate. In a certain sense, then, in these systems, candidate selection/deselection is decided by the voters as well as by the parties.

In sum, if a polity has a party-centered electoral system, small electoral districts, and centralized candidate selection, it will be relatively easy for party leaders to use traditional forms of political pressure to enforce party discipline. By contrast, if a polity has a candidatecentered electoral system, large electoral districts, and candidates are selected by local elites, parliamentary parties will have to use other mechanisms or incentives to secure party cohesion.

\section{Legislative-Executive Design AND FEDERALisM}

Other institutions-most notably, the structure of legislative-executive relations and the territorial organization of the state-also affect the re-

\footnotetext{
${ }^{10}$ Michael Gallagher, "Introduction," in Gallagher and Marsh, eds., Candidate Selection in Comparative Perspective: The Secret Garden of Politics (London: Sage, 1988); idem, "Conclusion," in Gallagher and Pippa Norris, "Conclusions: Comparing Passages to Power," in Norris, ed., Passages to Power: Legislative Recruitment in Advanced Democracies (Cambridge: Cambridge University Press, 1997); Lars Bille, "Democratizing a Democratic Procedure: Myth or Reality? Candidate Selection in Western European Parties, 1960-1990," Party Politics 7 (May 2001); Katz, "The Problem of Candidate Selection and Models of Party Democracy," Party Politics 7 (May 2001); and Gideon Rahat and Hazan, "Candidate Selection Methods: An Analytical Framework," Party Politics 7 (May 2001).

${ }^{1}$ Elmer E. Schattschneider, Party Government (New York: Holt, Rinehart and Winston, 1942), 1.
} 
lationship between politicians and party leaders and the consequent cohesion of parliamentary parties.

The structure of legislative-executive relations determines the extent to which parties in government can control their parliamentary supporters. In parliamentary systems, in which the chief executive is "fused" to a parliamentary majority, governing parties can reward loyal backbenchers with ministerial seats, and the reelection prospects of parliamentarians from the majority party are closely associated with the performance of their party leaders in government. Governing parties can also use a vote-of-confidence motion and the threat of parliamentary dissolution to force their backbenchers to follow voting instructions. ${ }^{12}$

In presidential systems, by contrast, parties controlling the executive do not have these resources. The executive does not depend on the support of a legislative majority and cannot dissolve the parliament. Hence, even if the party controlling the executive has a majority in the legislature, lack of party discipline in the legislature does not threaten the survival of the executive. Also, because the elections for the executive and legislative offices are held separately, the connection between the performance of a party in government and the reelection prospects of its representatives is less direct than in parliamentary systems. As a result, empirical research reveals that legislative parties in presidential systems are less cohesive than legislative parties in parliamentary systems. ${ }^{13}$

The level of decentralization of the state affects power relations between local and central party elites within a party's internal organization. ${ }^{14}$ In unitary states, where the main focus of parties is winning the national elections, parties tend to be hierarchical and dominated by their central leadership. Also, local party activists in these states may have different policy preferences on some issues from those of their central party leadership, but they have few incentives to voice their differences because their career prospects within the party are dependent on the central party leadership.

By contrast, in federal states, parties need to have separate organiza-

${ }^{12}$ See John Huber, "The Vote of Confidence in Parliamentary Democracies," American Political Science Review 90 (June 1996); and Daniel Diermeier and Timothy J. Feddersen, "Cohesion in Legislatures and the Vote of Confidence Procedure," American Political Science Review 92 (September 1998).

${ }^{13}$ Carey, "Getting Their Way, or Getting in the Way? Presidents and Party Unity in Legislative Voting," (Manuscript; Washington University, St. Louis; 2002).

${ }^{14}$ See William H. Riker, "Federalism," in Fred I. Greenstein and Nelson W. Polsby, eds., Governmental Institutions and Processes, vol. 5 of the Handbook of Political Science (Reading, Mass.: AddisonWesley, 1975); William M. Chandler, "Political Parties and Federalism," in Herman Bakvis and Chandler, eds., Political Parties and the State (Toronto: University of Toronto Press, 1987); and the chapters on federal states in Katz and Peter Mair, Party Organizations: A Data Handbook on Party Organizations in Western Democracies, 1960-90 (London: Sage Publications, 1992). 
tional structures for waging election campaigns at different levels of government. There is also likely to be greater preference for heterogeneity among voters in federal states than in unitary systems-a tendency attributable either to the reasons the state was federalized in the first place or to subsequent variances in policy outputs of state governments. Hence, as compared with parties in unitary state systems, statelevel parties in federal systems are likely to have greater incentives to take policy positions different from those of their central party leaderships and to choose candidates that share these policy preferences rather than candidates preferred by the central party leaderships. Hence, parliamentary parties are likely to be less cohesive in federal systems than in parliamentary systems, independent of the electoral institutions used.

\section{The European Parliament as a Laboratory}

The European Parliament is a good laboratory for isolating the impact of electoral institutions on individual legislative behavior. In contrast to legislative behavior in different state parliaments, voting in the European Parliament takes place within a single structure of legislativeexecutive relations and unitary-federal government. In the EU system, based on the separation of powers, the executive (the Commission) is elected by a special procedure, does not rely on a permanent majority in the European Parliament, and cannot dissolve the European Parliament. Moreover, all EU member states are essentially parliamentary systems. Even in France, which has a semipresidential system, parties in the cabinet behave much like governing parties in more classic parliamentary systems. ${ }^{15}$

Consequently, parliamentary parties in the European Parliament are more similar to parties in the United States Congress than to parties in European national parliaments, in which the European party groups control committee assignments and the agenda inside the parliament yet have few external powers, such as selecting candidates for parliamentary elections or controlling election campaigns. In a sense, as a laboratory, the European Parliament is like a hypothetical U.S. Congress with different electoral institutions in each U.S. state.

Furthermore, as Table 1 shows, there is significant variation in the types of electoral institutions used in European Parliament elections. At the top of the table are states with electoral systems and candidateselection rules that are likely to have national parties with a high degree

\footnotetext{
${ }^{15}$ See, in particular, Huber, Rationalizing Parliament: Legislative Institutions and Party Politics in France (Cambridge: Cambridge University Press, 1996).
} 


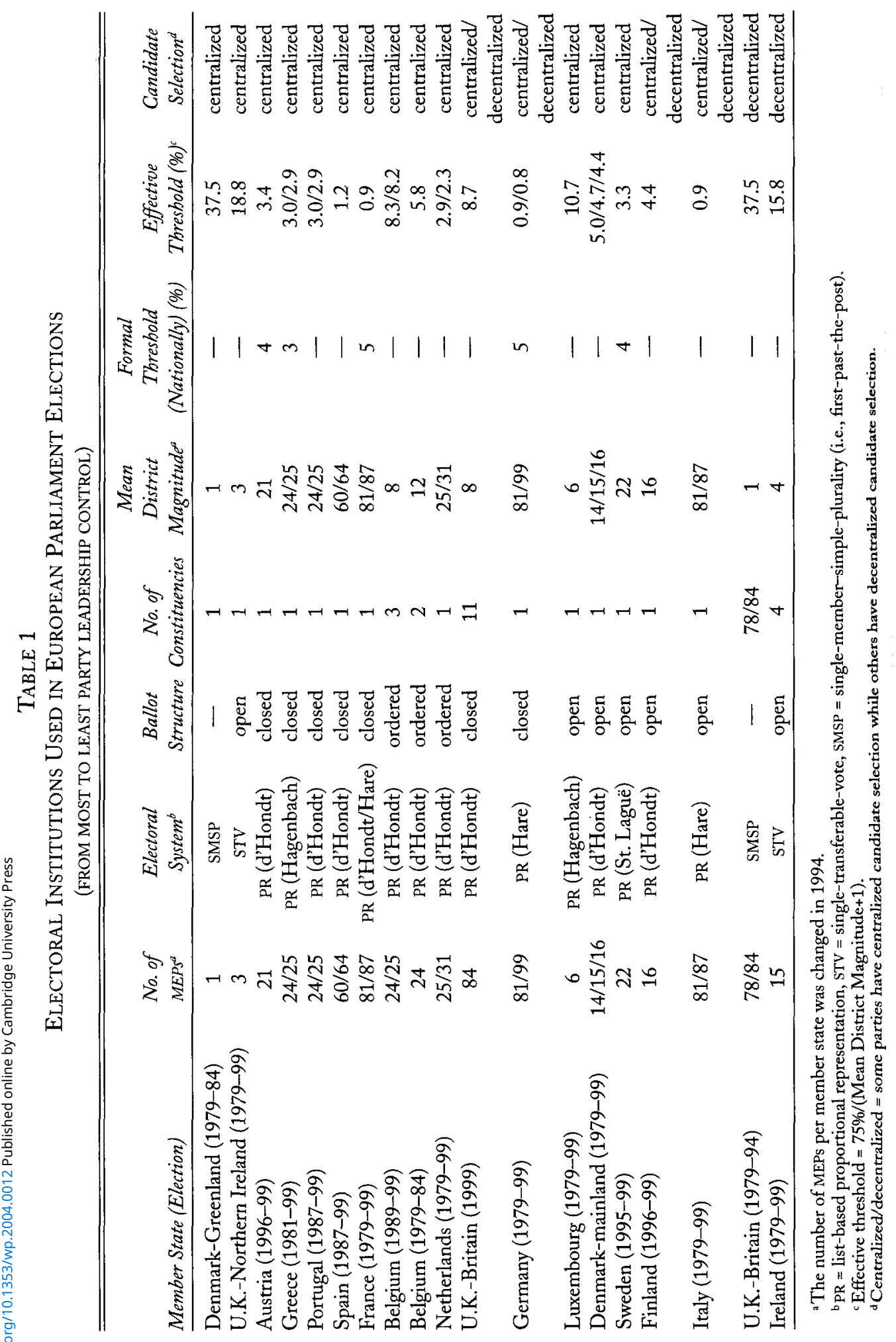


of control over their MEPs. In the middle of the table are states in which MEPs are likely to have a limited degree of autonomy. At the bottom of the table are states in which MEPs are likely to be highly autonomous.

\section{A Theory of Legislative Voting IN THE EUROPEAN PARLIAMENT}

We can analyze the relationship between electoral institutions and legislative behavior more explicitly with the aid of a simple decisiontheoretic model. ${ }^{16}$ The model starts by assuming that a Member of the European Parliament (MEP) pursues all the main goals usually attributed to politicians: winning reelection, securing policy, and obtaining higher office. An MEP may vote a particular way to enhance her chance of attracting votes, to promote a particular policy, or to secure assignment to a particular parliamentary office (such as the chairmanship of an influential committee).

We then assume that each MEP has two principals: her European parliamentary group and her national party. The national party is more influential than the European party group in influencing the MEP's likelihood of winning reelection because European elections are fought at the national level rather than at the European level; hence the popularity of an MEP's national party is more influential in determining an MEP's electoral chances. National parties also control an MEP's access to future office and influence in setting policy goals. MEPs may seek election to the national legislature, to national executive office, or otherwise attempt to influence national policy. Empirical research has shown, for example, that although an increasing number of MEPs have chosen to stay in the European Parliament, the European Commission, or the Brussels policy community, many do return or intend to return to pursue domestic political careers. ${ }^{17}$

By contrast, the European party group has more influence than the national party over MEPs' likelihood of securing their policy goals and obtaining higher office inside the European Parliament, because the European party group leaderships control the allocation of committee assignments and rapporteurships (reports on legislative dossiers), the parliamentary agenda, access to parliamentary group leadership positions and other offices in the parliament, and speaking time. Empirical

${ }^{16}$ This builds on the model in Matthew Gabel and Simon Hix, "The European Parliament and Executive Politics in the EU: Voting Behaviour and the Commission President Investiture Procedure," in Madeleine O. Hosli, Adrian Van Deemen, and Mika Widgrén, eds., Institutional Challenges in the European Union (London: Routledge, 2002), 28-32.

"Susan Scarrow, "Political Career Paths and the European Parliament," Legislative Studies Quarterly 22 (May 1997). 
research has shown that the cohesion of the European party groups has increased proportionally to the parties' power to control these offices and policy outcomes. ${ }^{18}$

Three parameters determine the likely costs and benefits of an MEP's vote decision. First, the level of conflict between the European party group and the national party on a particular vote determines the extent to which an MEP receives conflicting voting instructions from her two principals. In practice, it is not known whether there actually is a conflict between the two principals until after the European party group has taken a position in a vote. Once the European party group majority has decided to vote yes or no to abstain, the party whips send this information to each MEP in the group. At this stage, the European party group is aware that there may be a conflict between the group position and the position of some of the individual national delegations within the group. The majority decision of the European party group is, however, endogenous to the level of conflict with the national party members in the group; if enough national delegations in the party group had voted differently from the majority position, the outcome would have been different.

A national party can only observe a conflict between its position and the position of its party group once a majority position of a party group has been decided. If there is not a conflict, the majority in the national party simply will agree with the party group majority. When this occurs, the national party will not bother to issue separate voting instructions to its MEPs. ${ }^{19}$ But, if there is a conflict-if the national party takes a different position than the European party group-it will instruct its MEPs to vote against the party group's position.

In other words, because the size of internal conflict is endogenous to the party group majority's position on an issue, I assume that the party group does not act strategically when issuing voting instructions-the majority simply takes a position, which is then communicated to the backbenchers. By contrast, the national party may act strategically. If a national party is sure that its MEPs will follow its voting instructions and vote against their European party group, then it will not hesitate to issue the instructions; however, if the national party is unsure whether its MEPs will follow its instructions, it may decide not to issue them in the first place.

\footnotetext{
${ }^{18}$ See Abdul Noury and Gérard Roland, "More Power to the European Parliament?" Economic Policy 34 (October 2002); and Hix, Noury, and Roland, "Power to the Parties: Cohesion and Competition in the European Parliament, 1979-2001," British Journal of Political Science (forthcoming).

${ }^{19}$ This behaviour by national parties was confirmed in interviews with inter alia Richard Corbett MEP (British Labour Party), Michiel van Hulthen MEP (Dutch Labour Party), Heidi Hautala MEP (Finnish Green Party), and Klaus Welle, the secretary-general of the Group of the European People's Party-European Democrats.
} 
This leads to the second parameter: the cost $(N)$ that the national party can impose on an MEP if she defects from the national party's voting instructions. This is where the electoral institutions come in. Following the previous discussion, we can assume that the more centralized the system of candidate selection in the hands of the national party leadership, the more likely it is that the national party will be able to punish that MEP, regardless of the type of electoral system or the size of the MEP's electoral district. Furthermore, if an MEP is elected under a party-centered electoral system or in a small electoral district, the threat of moving the MEP down on the party list will be greater than for an MEP elected under a more candidate-centered electoral system or in a large electoral district, since in the latter settings, the MEP may be able to develop an independent identity from the party or stand as an independent candidate (as has often been the case with MEPs elected under Ireland's STV system). In addition, the more senior an MEP is in the national party, the more difficult it will be for the national party to remove her as a candidate.

The third parameter is the cost $(E)$ that the European party group can impose on an MEP if she fails to follow the party group's voting instructions. All party groups can remove MEPs from office and withdraw policy benefits. However, the large party groups, since they control the most offices and have the most influence on policy outcomes, probably have more opportunities to punish their MEPs. Party groups are also probably less able to punish MEPs who have been in the European Parliament for a long time, as they are likely to hold senior positions in the party group or the parliament as a whole that make them less vulnerable to acts of politically motivated retribution.

Accordingly, each MEP makes a vote decision based on the overall expected utility of her action. Formally, the utility function is defined as follows:

$\operatorname{MEP}\left(\mathrm{U}_{\mathrm{Yes}}\right)=E P G(E)+N P(N)$

where, EPG instruction $(E P G)$ :

No $(-1)$, Yes (1)

NP instruction $(N P)$ :

No $(-1)$, Yes (1)

Cost of defection from European

party group $(E)$ :

$0 \leq E \geq 1$

Cost of defection from national party $(N): \quad 0 \leq N \geq 1$

if $\operatorname{MEP}\left(\mathrm{U}_{\mathrm{Yes}}\right)>0$, then vote yes

if $\operatorname{MEP}\left(\mathrm{U}_{\mathrm{Yes}}^{\mathrm{Ses}}\right)<0$, then vote no

if $\operatorname{MEP}\left(\mathrm{U}_{\mathrm{Yes}}\right)=0$, then randomize between yes, no, and abstain 
Based on this expected utility model, there are two key types of vote decisions: a choice made when an MEP's national party and European party group are on the same side (a vote of either yes or no), and a choice made when her two principals are on opposing sides. In the first case, the MEP's vote decision will simply be to follow the instructions of the European party group (since the national party is unlikely to issue an instruction). In the second case, however, the MEP will decide as follows:

Vote with European party group against national party if: $N<E$

Vote with national party against European party group if: $N>E$

Randomize votes between party positions if: $\quad N=E$

Consequently, this model produces several predictions that can be tested empirically. First, when the positions of her European party group and national party do not conflict, an MEP will vote with her European party group. Second, when there is a conflict between an MEP's European party group and her national party, she is unlikely to vote against her European party group-unless she is elected under institutions that enable her national party to punish her to a politically appreciable extent. Third, national parties operating under electoral institutions make it difficult for them to impose costs on their MEPs should not issue voting instructions, as their MEPs should always vote with their European party groups (as long as $E>0$ ). Fourth, national parties operating under electoral institutions that enable them to impose costs on their MEPs should never have to use this sanction, as their MEPs should be able to predict their national party's reaction to a defection decision.

Regarding this fourth prediction, there are several well-known anecdotes about national parties demoting particular MEPs who have defied national party instructions. For example, in the 1994 European elections, Jean-Pierre Cot MEP, the leader of the Socialist Group in the 1989-94 parliament, was moved down on the French Socialist party list allegedly as punishment for continually refusing to follow instructions from Paris. Similarly, in the 1999 European elections, Carole Tongue MEP, a popular, high-profile British MEP who had been the rapporteur on several pieces of legislation on the regulation of media ownership, was placed fifth on the British Labour Party list in the London region, allegedly as punishment for refusing to tone down her criticism of media mogul Rupert Murdoch-a new ally of Tony Blair at the time. Since Labour won four MEP seats in London in 1999, Tongue was not reelected. In most cases, however, MEPs know whether their national parties can punish defection, and hence do not put themselves in positions similar to those of Cot and Tongue. 
To test this and the other predictions in a more systematic way, however, one should look beyond anecdotes, at a large number of individual MEP vote decisions.

\section{OPERATIONALIZATION: VOTING \\ IN THE EUROPEAN PARLIAMENT}

\section{DePendent VARIABLES: MEP Vote DeCisions, 1999-2000}

To test the theory, I collected the decisions of all MEPs in all roll-call votes taken during the first year of the 1999-2004 parliament. ${ }^{20} \mathrm{In}$ rollcall votes in the European Parliament, MEPs can register one of three vote decisions: yes, no, or abstain. ${ }^{21}$ The number of yes, no, and abstain votes are recorded in the European Parliament's minutes; 1,031 rollcall votes took place between July 1999 and June 2000 . In these votes, with 626 MEPs serving, there were 645,406 separate vote decisions. However, some of these vote decisions are not of relevance to my analysis-for example, in cases in which an MEP was not a member of any party group; the MEP's national party had too few representatives to determine which way the majority of the national party eventually voted (such as in parties with fewer than three MEPs); or an MEP did not participate in the vote (either the MEP was absent that day or the MEP signed the attendance register yet did not vote). Once these decisions were removed from analytical consideration, 396,167 vote decisions remained, by 526 MEPs (representing 82 percent of all MEPs serving during that period) from fifty-five national parties and fourteen member states (no parties from Luxembourg have at least three MEPs).

These basic vote decisions (yes, no, or abstain) were then recoded into two separate dependent variables: (1) whether an MEP's vote decision (yes, no, or abstain) was the same as or different from the majority decision of her European party group; and (2) whether an MEP's vote decision was the same as or different from the majority decision of her national party. In

\footnotetext{
${ }^{20}$ The data were collected as part of the "How MEPs Vote" project, in which Abdul Noury (Université Libre de Bruxelles), Gérard Roland (University of California, Berkeley), and I have compiled all the roll-call votes that took place in the European Parliament between 1979 and 2004 (approximately twelve thousand votes by two thousand MEPs). See Hix, "Legislative Behaviour and Party Competition in the European Parliament: An Application of Nominate to the EU," Journal of Common Market Studies 39 (November 2001); Noury and Roland (fn. 18); and Hix, Noury, and Roland (fn. 18).

${ }^{21}$ In other words, there are two different ways to abstain in a roll-call vote in the European Parliament: by registering an abstain vote, or by not participating in the vote. Arguably, both of these types of abstention are strategic. However, whereas an abstain vote is clearly strategic, since it involves going on record as abstaining, there are many nonstrategic reasons for nonparticipation, ranging from physical inability to be present at the time of a vote (connections to Strasbourg are few and far between) to decisions to use the time to conduct other important business. Hence, to capture the bulk of strategic abstentions, the registered abstain votes are included in the analysis, while the decisions not to participate are excluded.
} 
MEP Decision in Relation to

Her National Party

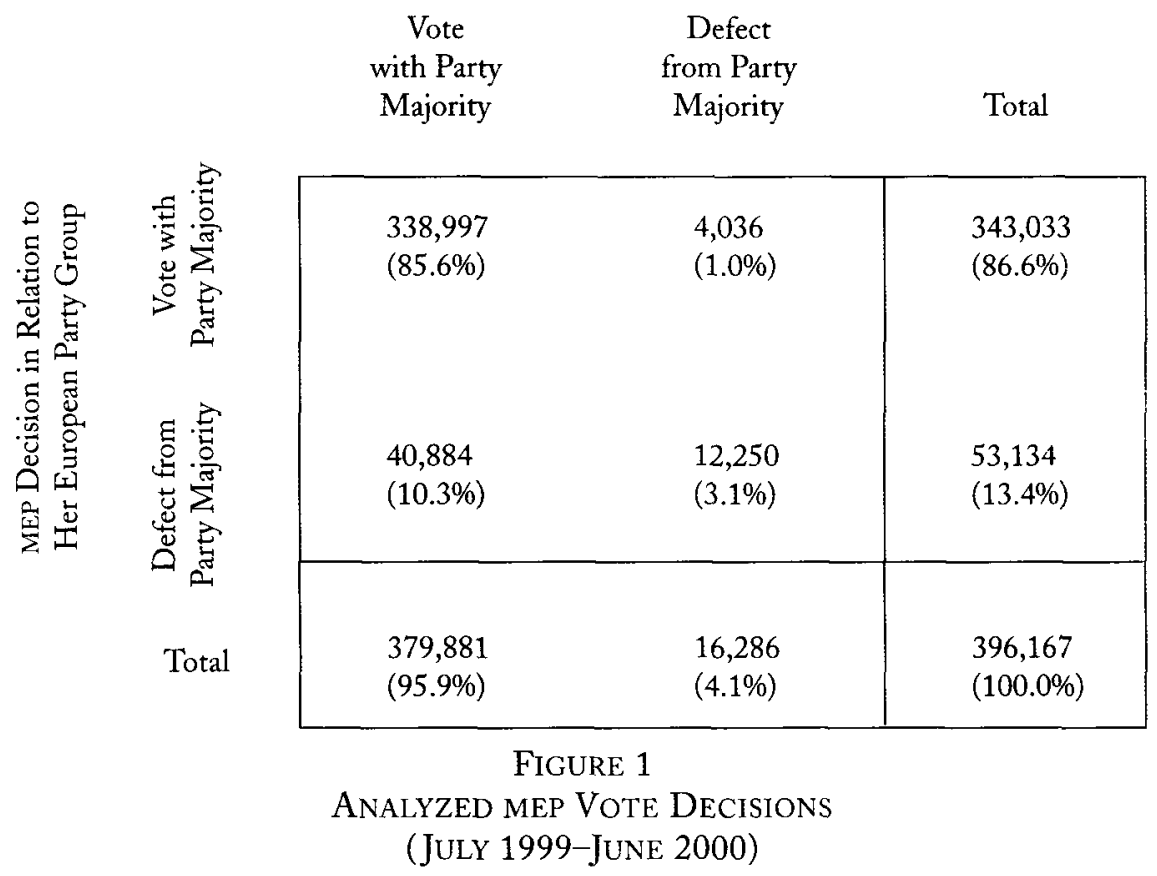

other words, if the majority of a party group voted yes, an MEP is considered to have defected from this group in a particular vote if she registered either a no or an abstain in the vote. The relationship between the two dependent variables is summarized in Figure 1.

As predicted, most of the time, MEPs voted the same way as the majorities of both their European party group and national party did. Also as predicted, MEPs were more likely to defect from their European party group than from their national party. There were actually more cases of "double defections" (from both the MEP's European party group and national party) than cases in which an MEP voted against her national party but with her European party group. However, only 7,504 of these double defections (comprising less than 2 percent of all MEP vote decisions during this period) represented cases in which MEPs expressed a directly opposing view from their party principals (by voting either yes or no against the majorities of both their European party groups and their national parties). The other 4,746 double defections represented cases in which MEPs voted to abstain-either when their two party 
principals were on the same side (voting yes or no together) or when their two principals were on opposing sides (with one voting yes and the other voting no).

\section{A Statistical Model of mep Defection}

To explain these MEP defection decisions and to test the predictions of the theoretical model, we can estimate the following fixed-effects logit model:

$$
\begin{aligned}
Z= & \beta_{f} E L I N S T_{m v}+\beta_{2} C O N F L_{m v}+\beta_{3} S E N_{m v}+\beta_{4} E P G_{m v}+\beta_{5} N P_{m v} \\
& +\beta_{6} V O T E_{v}+e_{m v} \\
m= & 1, \ldots, 526 \\
v= & 1, \ldots, 1031
\end{aligned}
$$

where, $Y_{m v}$ is a decision on whether to defect from a party by MEP $m$ in vote $v$, each MEP is indexed by $m$, each roll-call vote is indexed by $v$, and $\operatorname{Pr}\left(Y_{m v}=1\right)=\frac{1}{1+e^{-z}}$.

The model is estimated for two dependent variables: defection from a European party group, and defection from a national party. In both cases, the variable takes a value of one if an MEP defects in a vote decision, and a value of zero if an MEP votes with her European party (for the first dependent variable) or her national party (for the second dependent variable).

EL_INST is a vector of three variables that capture the independent effects of electoral and candidate-selection institutions and three variables that capture interaction effects between these institutions. Electoral System is a dummy variable that indicates the electoral system under which an MEP is elected and takes a value of one if an MEP is elected under a candidate-centered system (either a fully open-list PR or STV system) and a value of zero if an MEP is elected under a party-centered system (either a closed- or semiopen-list PR system). No member state used a SMSP, alternative-vote, or double-ballot system in the 1999 European elections. Candidate Selection is a dummy variable that indicates the candidate-selection rules under which an MEP is elected, and takes a value of one if an MEP is elected under centralized rules and a value of zero if an MEP is elected under decentralized rules. District Magnitude is a continuous variable that measures the magnitude of a candidate's electoral district.

To capture the effect of the interaction between the electoral and candidate-selection rules, three separate dummy variables are entered: one for each possible combination of the Electoral System and Candidate 
Selection variables, excluding the combination for which both variables equal zero (as a baseline). In other words, the first interaction variable (Candidate-centered + Decentralized-selection) takes a value of one only in those cases in which the two interaction variables both take a value of one. The second variable (Candidate-centered + Centralized-selection) takes a value of one only in those cases in which the Electoral System variable is one and the Candidate Selection variable is zero. And the third variable (Party-centered + Decentralized-selection) takes a value of one only in those cases in which the Electoral System variable is zero and the Candidate Selection variable is one. Because the two interaction variables are both dummy variables, this method allows the results to be interpreted more easily than if a single (multiplicative) interaction term is used.

CONFL is a vector of two variables that indicates the level of policy conflict between an MEP's national party and her European party group on the two main dimensions of EU politics. These are proxy measures of policy conflict between the two party principals. This, however, is preferable to using observed conflict in each vote because conflict in a particular vote is endogenous to the MEPs' vote decisions. As previously discussed, an MEP's two parties may be in conflict, but her national party may choose, for strategic reasons, not to issue voting instructions. Hence, exogenous measures are needed to gain leverage on the likelihood that an MEP's two principals will be on opposing sides of a vote.

Accordingly, the Left-Right Distance variable measures the distance between an MEP's national party and her European party group on the left-right dimension, while the EU Integration Distance variable measures the distance between an MEP's national party and her European party group on the EU-integration dimension (Appendix 2 explains how these measures are calculated). Given the relevance of these two dimensions to most issues on the European Parliament's agenda, these measures should give a good indication of the likelihood of policy conflict between the national parties and European party groups. ${ }^{22}$

SEN is a control variable that takes into account the "seniority" of an MEP in the European Parliament. This variable is operationalized as the length of time an MEP has been a member of the European Parliament (Length of Time in the EP). It is assumed to be a good indicator of the influence that the MEP has on the leadership of her party group and national delegation, and therefore, on setting the policy position of the

\footnotetext{
${ }^{22}$ Hix (fn. 20); idem, "Parliamentary Behavior with Two Principals: Preferences, Parties, and Voting in the European Parliament," American Journal of Political Science 46 (July 2002); and Noury, "Ideology, Nationality and Euro-Parliamentarians," European Union Politics 3 (March 2002).
} 
party group/national delegation on items on the agenda of the European Parliament. So, the more senior an MEP is, the less susceptible she will be to pressures from her European party group or her national party to toe the party line.

EPG is a vector of two dummy variables that controls for the effect of membership in the two largest party groups on MEP defection; EPP relates to the membership of the European People's Party-European Democrats, while PES relates to membership of the Party of European Socialists.

NP is a vector of ten dummy variables that controls for the effect of membership in the ten largest national party delegations (the main parties on the left and right in the five largest EU member states) on MEP defection. $C D U-G e r m a n y$ relates to the effect of membership in the German Christian Democratic Union, SPD-Germany relates to the effect of membership in the German Social Democratic Party, CONUnited Kingdom relates to the effect of membership in the British Conservative Party, LAB-United Kingdom relates to the effect of membership in the British Labour Party, RPR-France relates to the effect of membership in the main French Gaullist party, PS-France relates to the effect of membership in the French Socialist Party, FI-Italy relates to the effect of membership in Italy's main center-right party, $D S$-Italy relates to the effect of membership in the Italian Left Democrats, PPSpain relates to the effect of membership in the Spanish Popular Party, and PSOE-Spain relates to the effect of membership in the Spanish Socialist Workers Party.

VOTE is a vector of 1,031 dummy variables that indicate each vote; these variables are included to control for the effect of varying levels of defection and political salience of each vote.

The appendixes contain details of the data collection, the summary statistics, and the correlations between the variables.

\section{Predicted EFFECTS OF THE INDEPENDENT VARIABLES}

Table 2 summarizes the independent variables' predicted effects on the dependent variables; the electoral institution variables should be in opposite directions for the two dependent variables. The weaker the control an MEP's national party has under the electoral rules, the less likely it is that MEP will vote against her European party group. Hence, $\beta_{1}$ should be less than zero in the models of defection from the European party groups. Conversely, the weaker the control an MEP's national party has under the electoral rules, the more likely it is that MEP will vote against her national party. Hence, $\beta_{1}$ should be greater than zero in the models of defection from the national parties. 
TABLE 2

Predicted Effects of the IndePendent Variables

\begin{tabular}{llc}
\hline & \multicolumn{2}{c}{ Effect of an Increase in the Independent Variable } \\
\cline { 2 - 3 } & $\begin{array}{c}\text { On MEP Defection from } \\
\text { a European Party Group }\end{array}$ & $\begin{array}{c}\text { On MEP Defection } \\
\text { from a National Party }\end{array}$ \\
\hline $\begin{array}{l}\text { Independent Variables } \\
\text { Electoral institutions } \\
\text { i.e., candidate-centered voting system } \\
\text { decentralized candidate selection } \\
\text { large district magnitude }\end{array}$ & $\beta_{1}<0$ & $\beta_{1}>0$ \\
$\begin{array}{l}\text { Policy conflict between European } \\
\text { party group and national party } \\
\text { i.c., left-right distance } \\
\text { EU integration distance }\end{array}$ & $\beta_{2}>0$ & $\beta_{2}>0$ \\
\hline
\end{tabular}

By contrast, the policy conflict variables should have a similar directional effect on the two dependent variables. The greater the policy distance between an MEP's national party and her European party group, the more likely it is that the MEP will vote against her European party group and against her national party. Hence, $\beta_{2}$ should be greater than zero in all models.

\section{RESULTS}

\section{The Direction and Significance of Relationships}

Table 3 presents the estimates from four models of MEP defection from the European party groups. The beta coefficients compare the effects of the independent variables against the baseline group of MEPs - specifically, those MEPs that do not belong to either the EPP or the PES, the two largest party groups (the ten national parties in the analysis are members of one group or the other).

The effect of most of the independent variables is highly significant, primarily because of the large number of observations. More importantly for the theory, the direction of the effects is exactly as predicted. The less control a national party can exert over its MEPs as a result of the electoral institutions - if there is a candidate-centered electoral system, decentralized candidate selection, and a large district magnitude the less likely it is that an MEP from this party will vote against the majority position of her European party group. Moreover, when controlling for policy conflict between national parties and the European party group, this finding is confirmed. The further an MEP's national party is from her European party group (on either the left-right or the 
TABLE 3

MEP Voting Defection from European Party Groupsa

\begin{tabular}{|c|c|c|c|c|}
\hline Electoral Institutions & (1) & (2) & (3) & (4) \\
\hline $\begin{array}{l}\text { Electoral system } \\
\qquad(1=\text { candidate-centered })\end{array}$ & $\begin{array}{l}-.3345^{* * *} \\
(.0147)\end{array}$ & & $\begin{array}{l}-.1953^{* * *} \\
(.0208)\end{array}$ & \\
\hline $\begin{array}{l}\text { Candidate selection } \\
(1=\text { decentralized })\end{array}$ & $\begin{array}{l}-.2255^{* * *} \\
(.0119)\end{array}$ & & $\begin{array}{l}-.4152^{* * *} \\
(.0250)\end{array}$ & \\
\hline $\begin{array}{l}\text { Candidate-centered + } \\
\text { decentralized-selection }\end{array}$ & & $\begin{array}{l}-.5520^{* * * *} \\
(.0176)\end{array}$ & & $\begin{array}{l}-.4099^{* * *} \\
(.0286)\end{array}$ \\
\hline $\begin{array}{l}\text { Candidate-centered + } \\
\text { centralized-selection }\end{array}$ & & $\begin{array}{l}-.3527^{* * *} \\
(.0200)\end{array}$ & & $\begin{array}{l}-.4155^{* * *} \\
(.0226)\end{array}$ \\
\hline $\begin{array}{l}\text { Party-centered }+ \\
\text { decentralized-selection }\end{array}$ & & $\begin{array}{l}-.2352^{* * *} \\
(.0140)\end{array}$ & & $\begin{array}{l}-1.9613^{* * *} \\
(.0709)\end{array}$ \\
\hline District magnitude & $\begin{array}{l}-.0088^{* * * *} \\
(.0002)\end{array}$ & $\begin{array}{l}-.0088^{* * *} \\
(.0002)\end{array}$ & $\begin{array}{l}-.0024^{* * *} \\
(.0003)\end{array}$ & $\begin{array}{l}-.0038^{* * *} \\
(.0003)\end{array}$ \\
\hline \multicolumn{5}{|c|}{ Policy Confict between National Party and EP Group } \\
\hline Left-right distance & $\begin{array}{l}.1732^{* * *} \\
(.0101)\end{array}$ & $\begin{array}{l}.1750^{* * *} \\
(.0102)\end{array}$ & $\begin{array}{l}.3328^{* * *} \\
(.0131)\end{array}$ & $\begin{array}{l}.3090^{* * *} \\
(.0129)\end{array}$ \\
\hline EU-integration distance & $\begin{array}{l}.1880^{* * * *} \\
(.0061)\end{array}$ & $\begin{array}{l}.1895^{* * *} \\
(.0062)\end{array}$ & $\begin{array}{l}.1273^{* * *} \\
(.0085)\end{array}$ & $\begin{array}{l}.0691^{* * *} \\
(.0088)\end{array}$ \\
\hline \multicolumn{5}{|l|}{ Seniority } \\
\hline Length of time in the EP & $\begin{array}{l}-.0073^{* * * *} \\
(.0009)\end{array}$ & $\begin{array}{l}-.0074^{* * *} \\
(.0009)\end{array}$ & $\begin{array}{l}-.0064^{* * * *} \\
(.0010)\end{array}$ & $\begin{array}{l}-.0080^{* * *} \\
(.0010)\end{array}$ \\
\hline \multicolumn{5}{|c|}{ European Party Group Membership } \\
\hline EPP & & & $\begin{array}{l}-.6655^{* * *} \\
(.0184)\end{array}$ & $\begin{array}{l}-.7141^{* * *} \\
(.0184)\end{array}$ \\
\hline PES & & & $\begin{array}{l}.6512^{* * *} \\
(.0194)\end{array}$ & $\begin{array}{l}.5973^{* * *} \\
(.0193)\end{array}$ \\
\hline \multicolumn{5}{|l|}{ National Party Membership } \\
\hline CDU-Germany & & & $\begin{array}{l}.1147^{* *} \\
(.0433)\end{array}$ & $\begin{array}{l}1.7191^{* * *} \\
(.0802)\end{array}$ \\
\hline SPD-Germany & & & $\begin{array}{l}-.5193^{* * *} \\
(.0337)\end{array}$ & $\begin{array}{l}-.5262^{* * *} \\
(.0337)\end{array}$ \\
\hline CON-United Kingdom & & & $\begin{array}{l}1.5277^{* * *} \\
(.0331)\end{array}$ & $\begin{array}{l}3.0992^{* * *} \\
(.0746)\end{array}$ \\
\hline LAB-United Kingdom & & & $\begin{array}{l}-.4519^{* * * *} \\
(.0236)\end{array}$ & $\begin{array}{l}-.5489^{* * *} \\
(.0237)\end{array}$ \\
\hline RPR-France & & & $\begin{array}{r}.1195^{*} \\
(.0588)\end{array}$ & $\begin{array}{l}.1002 \\
(.0588)\end{array}$ \\
\hline PS-France & & & $\begin{array}{l}-.6776^{* * *} \\
(.0325)\end{array}$ & $\begin{array}{l}-.6735^{* * *} \\
(.0325)\end{array}$ \\
\hline FI-Italy & & & $\begin{array}{l}.7865^{* * *} \\
(.0457)\end{array}$ & $\begin{array}{l}.5249^{* * *} \\
(.0459)\end{array}$ \\
\hline
\end{tabular}


TABLE 3 (cont.)

\begin{tabular}{|c|c|c|c|c|}
\hline National Party Membership (cont.) & (1) & (2) & (3) & (4) \\
\hline DS-Italy & & & $\begin{array}{c}.0168 \\
(.0425)\end{array}$ & $\begin{array}{l}-.2864 \\
(.0430)\end{array}$ \\
\hline PP-Spain & & & $\begin{array}{c}-.0604 \\
(.0334)\end{array}$ & $\begin{array}{c}-.0910^{* *} \\
(.0334)\end{array}$ \\
\hline PSOE-Spain & & & $\begin{array}{l}-.8189^{* * *} \\
(.0305)\end{array}$ & $\begin{array}{l}-.8371 \\
(.0305)\end{array}$ \\
\hline$N$ (no. of vote decisions) & 396,167 & 393,806 & 393,806 & 396,167 \\
\hline Log likelihood & -141676.86 & -141675.97 & -137860.18 & -137377.47 \\
\hline
\end{tabular}

In a two-tailed test, ${ }^{*} \operatorname{Pr}(t>1.960)=.05,{ }^{* *} \operatorname{Pr}(t>2.576)=.01,{ }^{* * *} \operatorname{Pr}(t>3.090)=.001$

${ }^{\mathrm{a}}$ Dependent variable $=$ MEP vote decision to defect from her EP party group ( $1=$ defect, $0=$ not defect $)$. Fixed effects (dummy variables) for each of the 1,031 votes are included in all the models but are not reported.

EU-integration dimension), the more likely it is that the MEP will vote against her European party group.

The results of the interaction between the electoral system and candidate-selection rules (see models 2 and 4) reinforce these findings. A candidate-centered electoral system reduces MEP defection from a party group, regardless of whether there are centralized or decentralized candidate-selection rules. Similarly, decentralized candidate-selection rules reduce MEP defection from a party group, regardless of whether there is a candidate-centered or a party-centered electoral system.

These findings, in terms of the direction and significance of the relationships, do not change when dummies are introduced for the two main European party groups and the ten largest national party delegations (see models 3 and 4); however, their introduction does change the size of the coefficients for several key variables. Specifically, it significantly increases the size of the effect of candidate-selection rules. This suggests that the effect of centralized/decentralized candidate selection is even stronger for smaller national parties (which have less candidates and less elected politicians). This is similar to the effect of district magnitude, a phenomenon in which the smaller the number of candidates, the greater the effect electoral and candidate-selection rules will be on the incentives for candidates to support or oppose their party leaders.

Table 4 shows the estimates from four models of MEP defection from national parties. The direction of the effects here is also as predicted. In all models, if an MEP is elected under candidate-centered voting rules, with decentralized candidate-selection rules, or in a district with a large magnitude, that MEP is more likely to vote against her national party.

Nevertheless, the interaction effects in models 6 and 8 produce some 
TABLE 4

MEP Voting Defection fRom National Parties ${ }^{a}$

\begin{tabular}{|c|c|c|c|c|}
\hline Electoral Institutions & (5) & (6) & (7) & (8) \\
\hline $\begin{array}{l}\text { Electoral system } \\
\qquad(1=\text { candidate-centered })\end{array}$ & $\begin{array}{l}.2280^{* * *} \\
(.0255)\end{array}$ & & $\begin{array}{l}.0462 \\
(.0384)\end{array}$ & \\
\hline $\begin{array}{l}\text { Candidate selection } \\
\text { (1=decentralized })\end{array}$ & $\begin{array}{l}.1206^{* * *} \\
(.0193)\end{array}$ & & $\begin{array}{l}.2790^{* * *} \\
(.0409)\end{array}$ & \\
\hline $\begin{array}{l}\text { Candidate-centered + } \\
\text { decentralized-selection }\end{array}$ & & $\begin{array}{l}.4656^{* * *} \\
(.0273)\end{array}$ & & $\begin{array}{l}.3988^{* * *} \\
(.0473)\end{array}$ \\
\hline $\begin{array}{l}\text { Candidate-centered + } \\
\text { centralized-selection }\end{array}$ & & $\begin{array}{l}-.1567^{* * *} \\
(.0388)\end{array}$ & & $\begin{array}{l}-.1295^{* *} \\
(.0435)\end{array}$ \\
\hline $\begin{array}{l}\text { Party-centered + } \\
\text { decentralized-selection }\end{array}$ & & $\begin{array}{l}-.0485^{*} \\
(.0230)\end{array}$ & & $\begin{array}{l}-.3896^{* * *} \\
(.0853)\end{array}$ \\
\hline District magnitude & $\begin{array}{l}.0045^{* * *} \\
(.0003)\end{array}$ & $\begin{array}{l}.0047^{* * *} \\
(.0003)\end{array}$ & $\begin{array}{l}.0094^{* * * *} \\
(.0005)\end{array}$ & $\begin{array}{l}.0086^{* * *} \\
(.0005)\end{array}$ \\
\hline \multicolumn{5}{|c|}{ Policy Conflict between National Party and EP Group } \\
\hline Left-right distance & $\begin{array}{l}.1679^{* * *} \\
(.0161)\end{array}$ & $\begin{array}{l}.1854^{* * *} \\
(.0159)\end{array}$ & $\begin{array}{l}.1298^{* * *} \\
(.0210)\end{array}$ & $\begin{array}{l}.1172^{* * *} \\
(.0209)\end{array}$ \\
\hline EU integration distance & $\begin{array}{l}.1053^{* * *} \\
(.0113)\end{array}$ & $\begin{array}{l}.1344^{* * *} \\
(.0113)\end{array}$ & $\begin{array}{c}-.0231 \\
(.0160)\end{array}$ & $\begin{array}{c}-.0625^{* * *} \\
(.0165)\end{array}$ \\
\hline \multicolumn{5}{|l|}{ Seniority } \\
\hline Length of time in the EP & $\begin{array}{l}.0095^{* * *} \\
(.0015)\end{array}$ & $\begin{array}{l}.0096^{* * *} \\
(.0015)\end{array}$ & $\begin{array}{l}.0181^{* * *} \\
(.0015)\end{array}$ & $\begin{array}{l}.0170^{* * *} \\
(.0015)\end{array}$ \\
\hline \multicolumn{5}{|c|}{ European Party Group Membership } \\
\hline EPP & & & $\begin{array}{l}-.0431 \\
(.0274)\end{array}$ & $\begin{array}{c}-.0666^{*} \\
(.0275)\end{array}$ \\
\hline PES & & & $\begin{array}{l}.1484^{* * *} \\
(.0376)\end{array}$ & $\begin{array}{l}.1166^{* * *} \\
(.0376)\end{array}$ \\
\hline \multicolumn{5}{|l|}{ National Party Membership } \\
\hline CDU-Germany & & & $\begin{array}{l}-.7147^{* * * *} \\
(.0618)\end{array}$ & $\begin{array}{c}-.0197 \\
(.0988)\end{array}$ \\
\hline SPD-Germany & & & $\begin{array}{l}-.8871^{\text {*k*k }} \\
(.0598)\end{array}$ & $\begin{array}{l}-.9002^{* * *} \\
(.0598)\end{array}$ \\
\hline CON-United Kingdom & & & $\begin{array}{l}.2213^{* * * *} \\
(.0575)\end{array}$ & $\begin{array}{l}.8971^{* * *} \\
(.0949)\end{array}$ \\
\hline LAB-United Kingdom & & & $\begin{array}{l}-.4109^{* * *} \\
(.0529)\end{array}$ & $\begin{array}{l}-.4802^{* * *} \\
(.0531)\end{array}$ \\
\hline RPR-France & & & $\begin{array}{c}-.5872^{* * *} \\
(.0918)\end{array}$ & $\begin{array}{c}-.6160^{* * *} \\
(.0919)\end{array}$ \\
\hline PS-France & & & $\begin{array}{c}-.5793^{* * *} \\
(.0565)\end{array}$ & $\begin{array}{c}-.5847^{*} \\
(.0564)\end{array}$ \\
\hline FI-Italy & & & $\begin{array}{l}.7629^{* * *} \\
(.0589)\end{array}$ & $\begin{array}{l}.6389^{* * *} \\
(.0596)\end{array}$ \\
\hline
\end{tabular}


TABLE 4 (cont.)

\begin{tabular}{|c|c|c|c|c|}
\hline National Party Membership (cont.) & (5) & (6) & (7) & $(8)$ \\
\hline DS-Italy & & & $\begin{array}{r}-.1766^{*} \\
(.0733)\end{array}$ & $\begin{array}{c}-.3230^{* *+1} \\
(.0742)\end{array}$ \\
\hline PP-Spain & & & $\begin{array}{l}-.4766^{* * *} \\
(.0495)\end{array}$ & $\begin{array}{c}-.5089^{*} \\
(.0496)\end{array}$ \\
\hline PSOE-Spain & & & $\begin{array}{c}-.6137^{* * *} \\
(.0559)\end{array}$ & $\begin{array}{c}-.6326 \\
(.0559)\end{array}$ \\
\hline $\mathrm{N}$ (no. of vote decisions) & 393,806 & 393,806 & 393,806 & 393,806 \\
\hline Log likelihood & -60635.37 & -60525.69 & -60171.85 & -60120.87 \\
\hline
\end{tabular}

In a two-tailed test, ${ }^{*} \operatorname{Pr}(t>1.960)=.05,{ }^{* *} \operatorname{Pr}(t>2.576)=.01,{ }^{* * *} \operatorname{Pr}(t>3.090)=.001$

${ }^{a}$ Dependent variable $=$ MEP vote decision to defect from her national party $(1=$ defect, $0=$ not defect $)$. Fixed effects (dummy variables) for each of the 1,031 votes are included in all the models but are not reported, although 21 votes (2,361 observations) were dropped because there was no variation in this dependent variable.

interesting results. An MEP is more likely to vote against her national party only when she is elected under a candidate-centered system with decentralized candidate-selection rules. Unlike in the models of European party group defection, in the models of national party defection, the effect of centralized candidate selection dominates the effect of a candidate-centered electoral system, but the effect of a party-centered electoral system dominates the effect of decentralized candidate selection. In other words, MEPs are less likely to defect from their national parties if there is either a party-centered electoral system or centralized candidate selection.

The further an MEP's national party is from her European party group on the left-right dimension, the more likely it is that MEP will be torn between the position of her European party group and that of her national party and hence will vote against the national party. The effect of the EU-integration policy distance between a national party and its European party group, however, is less clear.

Finally, as expected, the longer an MEP has been in the European Parliament, the less likely it is that she will vote against her European party group, but the more likely it is that she will vote against her national party; this suggests that the longer an MEP serves in the European Parliament, the more likely it is that she will become both a key player in setting her party group's position and independent from national party influence.

\section{The Probability of Defection}

These results consequently confirm that electoral rules have an impact on how MEPs behave vis-à-vis their European party groups and national par- 


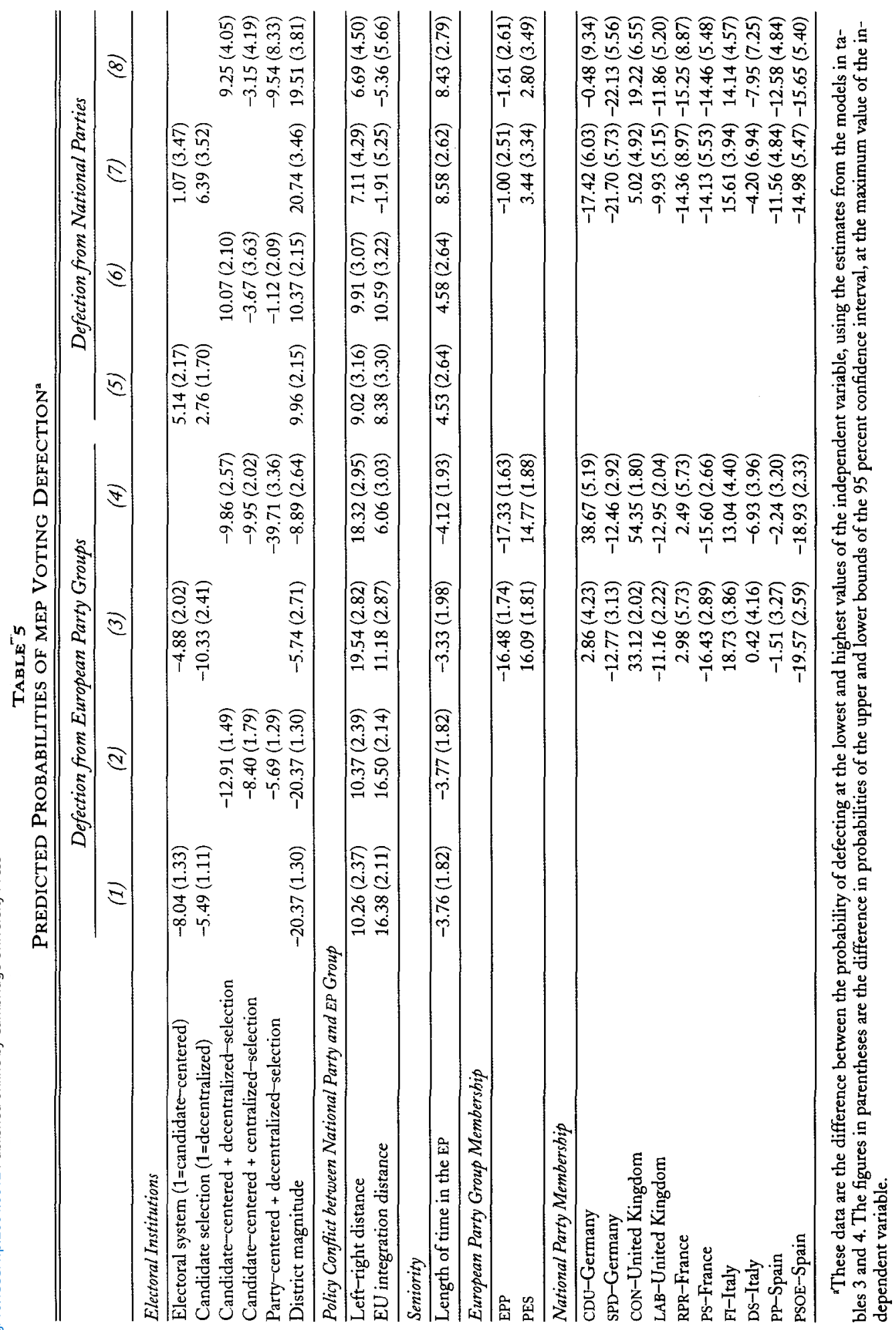


ties. To investigate this impact in more detail, however, we need to look beyond the direction of the effects and make a substantive interpretation of the strength of these effects. ${ }^{23}$ In logit analysis, this requires calculating the conditional probability of MEPs voting against their European party groups/national parties for different values of the independent variables.

Table 5 shows the effects of maximal variation in the independent variables on the probability that an MEP will vote against her European party group or national party (the figures in parentheses represent the difference in percent of the probabilities at the upper and lower limits of the 95 percent confidence interval). Focusing on the key claims of the theory, the individual effects of each of the three types of electoral institutions might seem small; however, the cumulative effects are large. An MEP chosen via institutions that afford her a high level of independence from her national party leadership is more than 30 percent less likely to vote against her European party group than an MEP elected under the alternative set of institutions. Conversely, an MEP chosen via institutions that provide a high level of control to her national party leadership is approximately 20 percent less likely to vote against her national party than an MEP elected under the alternative set of institutions.

The predicted probabilities are also interesting for the two European party groups and the national parties. Controlling for the membership of the main national party delegations in the groups, members of the European People's Party are approximately 16 percent less likely to vote against their European party group than the average MEP, while members of the Party of European Socialists are 15 percent more likely to vote against their European party group.

However, because of the structure of the model, these results for the two main European party groups apply only to those MEPs who are not members of the five largest national delegations in these party groups. Two of the large national delegations in the European People's Partythe British Conservatives and Forza Italia-have highly independentminded MEPs. In Model 3, for example, British Conservative MEPs are 33 percent ( \pm 2 percent) more likely to vote against their European party group than the average MEP, and in Model 8 they are 19 percent ( \pm 7 percent) more likely to defect from their national party. These results reflect the ideological distance of the average British Conservative MEP from the median member of the European People's Party group on both the left-right and the EU-integration dimensions-a situation that puts many British MEPs in a difficult position.

\footnotetext{
${ }^{23}$ See, for example, J. Scott Long, Regression Models for Categorical and Limited Dependent Variables (Thousand Oaks, Calif: Sage, 1997).
} 
Interestingly, the national party results suggest that the design of legislative-executive relations and the structure of territorial government at the domestic level does not affect individual legislative behavior in the European Parliament. MEPs from the two main parties in France, the only semipresidential system under analysis, are less likely to defect from their national party than the average MEP, and behave in the opposite way vis-à-vis their European party groups. Similarly, MEPs from the two main parties in Germany, the only federal system of the large EU member states, are less likely to defect from their national party than the average MEP and also behave in the opposite way vis-à-vis their European party groups.

\section{CONCLUSION}

At the microlevel, electoral institutions shape the relationship between elected politicians and their local and parliamentary principals. For example, if a politician's local electorate and parliamentary party leaders have conflicting policy preferences on a key issue, the nature of the electoral institutions will determine which of these two principals the politician will seek to placate. In such a scenario, if the electoral system allows candidates to cultivate support with the electorate independently of their party, or if local party elites control the selection and deselection of candidates, the politician is likely to vote against her party leadership. However, if the electoral system is party centered or if the party leadership controls the selection of candidates, the politician is likely to vote with her party leadership and against the wishes of local party elites and voters in her district.

These hypotheses were tested in the laboratory of the European Parliament, which for analytical purposes has the advantage of containing a variety of electoral institutions within a single structure of legislativeexecutive relations and state territorial organization. The results reveal that national parties are more able to enforce their wishes on their MEPs in systems containing electoral institutions that provide these principals with strong controls - specifically, in systems with closed-list proportional representation, small districts, or centralized candidate selection. Conversely, in systems with open-list PR, large districts, or decentralized candidate selection, MEPs are more independent agents and hence are freer to vote with their European party groups and against their national parties.

These microlevel findings have macrolevel implications. In the specific context of the European Parliament, the design of a single elec- 
toral system for the European Parliament will determine who ultimately controls the MEPs. If a system that allows national parties to control their MEPs is chosen, party cohesion in the European Parliament can be expected to decline. However, if electoral institutions that limit the ability of national parties to control their MEPs are chosen, the cohesiveness of the transnational parties will increase, and the European party groups will become powerful actors in the EU polity.

In the general context, parliamentary party cohesion is dependent upon the type of electoral system and the rules governing candidate selection, controlling for other constitutional arrangements, such as legislative-executive relations or the unitary/federal structure of the state. In some respects, the general inference of this research is in the opposite direction to the situation in the European Parliament. In the European Parliament, mesolevel parties (national parties), rather than local parties or parliamentary parties, control candidate selection and fight election campaigns. Hence, if electoral institutions weaken the ability of these principals to control their parliamentary agents, parliamentary party cohesion will increase. By contrast, in most other systems, parliamentary parties control candidate selection and fight elections. Hence, if electoral institutions weaken the power of these principals, parliamentary party cohesion will decrease.

Nevertheless, there is a single unifying logic: parliamentary party cohesion depends on the relative ability of parliamentary parties and local parties (or voters) to control "their" politicians, as well as on the heterogeneity of preferences between these two principals. At one extreme, parliamentary party cohesion will be highest if elections are fought centrally under a party-centered system and parliamentary party elites therefore control the selection of candidates (as in many continental European parliamentary systems). At the other extreme, parliamentary party cohesion will be lowest if elections are fought locally under a party-centered system and local parties therefore control candidate selection (as in the European Parliament and in U.S. congressional elections during certain periods). As a result, the effect of introducing institutions that increase candidate independence will depend on the starting point: it will reduce parliamentary party cohesion in the former case but will increase parliamentary party cohesion in the latter.

\section{APPENDIX 1: CODING OF THE VARIABLES}

The data for the dependent variables were compiled from the voting records of MEPs in all roll-call votes taken between July 1999 and June 
2000, as recorded in the Minutes of the European Parliament Plenary Sessions and as published in the Official Journal of the European Communities.

The data for the electoral system variables were collected from $\mathrm{Eu}$ ropean Parliament documents on the electoral rules used in each member state during the June 1999 European Parliament elections. ${ }^{24}$ The data for the Candidate Selection variable were taken from a survey of MEPs and national party officials (by Tapio Raunio) on relations between national parties and MEPs. ${ }^{25}$ One of the survey questions asked the MEPs how they were chosen to be candidates.

The data for the policy conflict variables were calculated from questions in a survey of MEPs (conducted by the European Parliament Research Group [EPRG]), in which MEPs were asked inter alia to locate themselves on two ten-point scales: one relating to the left-right continuum, and the other to EU integration. ${ }^{26}$ One hundred ninety-five MEPs ( 31 percent of the 626 members) completed the survey, and these returns constitute a good sample of the total population of MEPs. ${ }^{27}$

From these data, policy conflict between an MEP's European party group and her national party was calculated as the absolute distance between the mean self-placement of the members of her national delegation on the relevant dimension and the mean self-placement of the members of her European Parliament party group on the same dimension.

The data for the seniority variable were measured as the total number of years that the MEP has served in the European Parliament, with 1979 as the baseline. These data were constructed from the List of Members documents (which are published every six months by the $\mathrm{Eu}-$ ropean Parliament) since 1979..$^{28}$

The data for the European party group and national party variables were collected from the List of Members documents for the 19992000 period.

\footnotetext{
${ }^{24}$ European Parliament, Laws Governing the European Parliament Elections, final ed. (Brussels: European Parliament-DG for Information and Public Relations, 1999).

${ }_{25}$ Tapio Raunio, "Losing Independence but Gaining Recognition? Contacts Between MEPs and National Parties," Party Politics 6 (April 2000).

${ }^{26}$ See the European Parliament Research Group (EPRG) homepage (http://www.lse.ac.uk/depts /eprg, accessed October 23, 2003).

${ }_{2 i}$ Hix (fn. 22).

${ }^{28}$ See, for example, European Communities, List of Members, 29-09-2000 (Luxembourg: Office of Official Publications of the European Communities, 2000).
} 


\section{APPENDIX 2: SUMMARY STATISTICS}

\begin{tabular}{|c|c|c|c|c|}
\hline Variable & Mean & $\begin{array}{l}\text { Standard } \\
\text { Deviation }\end{array}$ & Minimum & Maximum \\
\hline Defection from European party group & .1341 & .3408 & 0 & 1 \\
\hline Defection from national party & .0411 & .1985 & 0 & 1 \\
\hline Voting system $(1=$ candidate-centered $)$ & .1789 & .3833 & 0 & 1 \\
\hline Candidate selection ( 1 =decentralized) & .2975 & .4571 & 0 & 1 \\
\hline $\begin{array}{l}\text { Candidate-centered }+ \\
\text { decentralized-selection }\end{array}$ & .1084 & .3109 & 0 & 1 \\
\hline $\begin{array}{l}\text { Candidate-centered }+ \\
\text { centralized-selection }\end{array}$ & .0705 & .2560 & 0 & 1 \\
\hline Party-centered + & & & & \\
\hline decentralized-selection & .1892 & .3916 & 0 & 1 \\
\hline District magnitude & 49.80 & 36.52 & 3 & 99 \\
\hline Left-right distance & .6695 & .5044 & 0 & 2.4 \\
\hline EU-integration distance & 1.078 & .8008 & .005 & 3.54 \\
\hline Length of time in the & & & & \\
\hline European Parliament & 4.790 & 5.369 & 0 & 21 \\
\hline EPP & .4114 & .4921 & 0 & 1 \\
\hline PES & .3419 & .4744 & 0 & 1 \\
\hline CDU-Germany & .0971 & .2961 & 0 & 1 \\
\hline SPD-Germany & .0668 & .2497 & 0 & 1 \\
\hline CON-United Kingdom & .0723 & .2590 & 0 & 1 \\
\hline LAB-United Kingdom & .0612 & .2398 & 0 & 1 \\
\hline RPR-France & .0109 & .1039 & 0 & 1 \\
\hline PS-France & .0433 & .2036 & 0 & 1 \\
\hline FI-Italy & .0249 & .1558 & 0 & 1 \\
\hline DS-Italy & .0269 & .1618 & 0 & 1 \\
\hline Pp-Spain & .0552 & .2283 & 0 & 1 \\
\hline PSOE-Spain & .0430 & .2028 & 0 & 1 \\
\hline
\end{tabular}




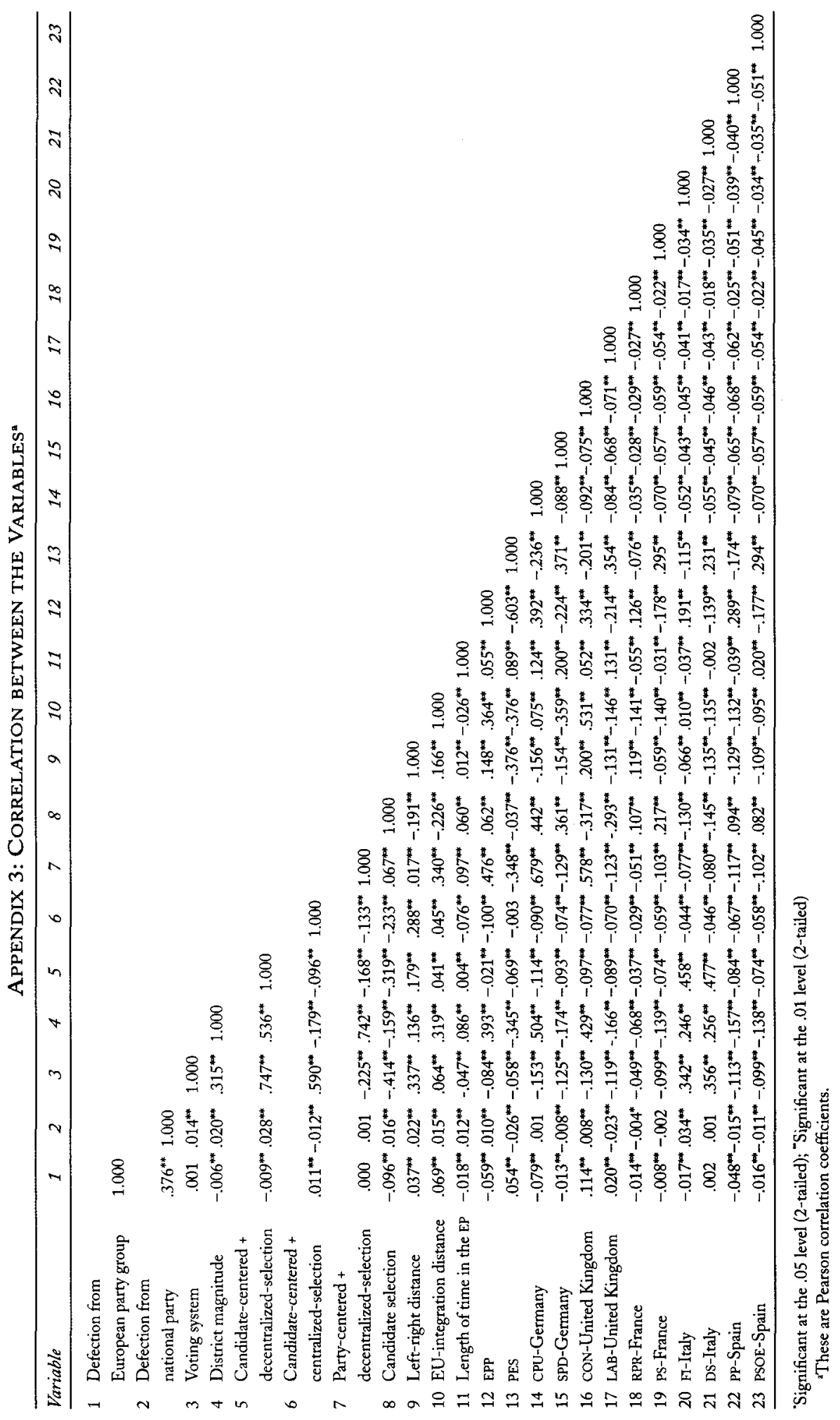

